\title{
Antagonistic and synergistic responses to solar ultraviolet radiation and increased temperature of phytoplankton from cenotes (sink holes) of the Yucatán Peninsula, México
}

\author{
Virginia E. Villafañe ${ }^{1,2,7}$, Sergio D. Guendulain-García ${ }^{3,8}$, Francisco Valadez ${ }^{4,5,9}$, \\ Gabriela Rosiles-González $^{5,10}$, E. Walter Helbling ${ }^{1,2,11}$, and Anastazia T. Banaszak ${ }^{6,12}$ \\ ${ }^{1}$ Estación de Fotobiología Playa Unión, Rawson, Chubut, Argentina \\ ${ }^{2}$ Consejo Nacional de Investigaciones Científicas y Técnicas (CONICET), Argentina \\ ${ }^{3}$ Posgrado de Ciencias del Mar y Limnología, Universidad Nacional Autónoma de México, Unidad Académica de Sistemas \\ Arrecifales, Puerto Morelos, México \\ ${ }^{4}$ Laboratorio de Humedales, CICART, División Académica de Ciencias Biológicas, Universidad Juárez Autónoma de Tabasco, \\ México \\ ${ }^{5}$ Unidad de Ciencias del Agua, Centro de Investigación Científica de Yucatán A.C., México \\ ${ }^{6}$ Instituto de Ciencias del Mar y Limnología, Universidad Nacional Autónoma de México, Unidad Académica de Sistemas \\ Arrecifales, Puerto Morelos, México
}

\begin{abstract}
Cenotes (sink holes) are karstic formations characteristic of the Yucatán Peninsula and are the main source of fresh water in the region. Because of their tropical location, they receive high levels of solar radiation and are exposed to high temperatures. However, the effect of these global-change-related variables on phytoplankton in cenotes is unknown. We carried out experiments with phytoplankton communities collected from 2 cenotes differing in their penetration of solar radiation (Leona Vicario [LV]: turbid, Las Mojarras [LM]: clear) to assess the combined effect of solar ultraviolet radiation (UVR; $280-400 \mathrm{~nm}$ ) and increased temperature on their photosystem (PS) II photochemistry. We exposed samples in microcosms to solar radiation (with and without UVR) and 2 temperatures (ambient $=25^{\circ} \mathrm{C}$ and increased by $3^{\circ} \mathrm{C}$ ) and analyzed photochemical performance over daily cycles. A significant antagonistic interaction between UVR and temperature in LV caused a combined inhibition of the effective photochemical quantum yield $\left(\Phi_{\mathrm{PSII}}\right)$ that was smaller $(63 \%)$ than the sum of the 2 individual effects of UVR and temperature (116\%). In contrast, a significant synergistic interaction between UVR and temperature in LM caused the combined inhibition of $\Phi_{\text {PSII }}(172 \%)$ to be higher than the sum of the individual effects of the 2 variables (134\%). Differences in the size distribution and taxonomic composition of the phytoplankton communities, with smaller cells in LV than in LM, seem to account for much of the variability in responses to UVR and increased temperature between the 2 communities. Our results suggest that phytoplankton communities from clear cenotes will be more affected by the combined effects of solar UVR and increased temperature that those from turbid cenotes.
\end{abstract}

Key words: cenotes, global change, phytoplankton, PSII photochemistry, temperature, ultraviolet radiation

Climate change affects terrestrial (Ballaré et al. 2011) and aquatic (Häder et al. 2011) organisms and ecosystems. Climate change is a complex process, but some of its main outcomes are increased global temperatures (IPCC 2013) and solar radiation levels that reach aquatic systems (Häder et al. 2011). These 2 variables associated with climate change are interrelated such that the increase in temperature, which is expected to be 2.6 to $4.8^{\circ} \mathrm{C}$ (scenario
RCP8.5) by the year 2100 (IPCC 2013), can be translated into increased (i.e., shallower and stronger) stratification of freshwater bodies (Vincent 2009, Wahl and Peeters 2014) with concomitant higher exposure of aquatic organisms to solar radiation. For phytoplankton, increased levels of solar radiation, and particularly of ultraviolet radiation (UVR; 280-400 nm), affect different targets (e.g., photosystems, the DNA molecule, membranes) and have

E-mail addresses: ${ }^{7}$ virginia@efpu.org.ar; ${ }^{8}$ wendous@hotmail.com; ${ }^{9}$ fvc_2001@yahoo.com; ${ }^{10}$ gabriela.rosiles@cicy.mx; ${ }^{11}$ whelbling@efpu.org.ar;

${ }^{12}$ banaszak@cmarl.unam.mx 
negative effects on diverse metabolic processes, such as photosynthesis, growth, and calcification (Beardall and Raven 2004), although with a high degree of species-specific variability. However, increased temperatures will tend to benefit organisms by increasing metabolic activity, provided that they are adapted to or can acclimate to an optimal temperature higher than the current water temperature and that growth is not limited by other factors (Beardall and Raven 2004).

The responses of organisms to a single factor (e.g., UVR or temperature) frequently are altered by antagonistic or synergistic interactions among environmental variables (Dunne 2010). For example, increased temperatures and UVR acted synergistically to reduce the growth of some marine tropical diatoms but not of other groups ( $\mathrm{Ha}-$ lac et al. 2013). On the other hand, these 2 variables acted antagonistically in marine temperate waters (Villafañe et al. 2013), where temperature counteracted the negative effects of UVR. This variability in responses added to the high diversity of aquatic environments in tropical regions, e.g., coral reefs, salt marshes, lagoons, and cenotes, makes generalizing or extrapolating these results to other species, communities, or even ecosystems ill-advised.

The objective of our study was to assess the potential effect of variables associated with climate change-solar radiation and temperature-on phytoplankton from a less familiar ecosystem: the cenotes of the Yucatán Peninsula in México. The hydrogeology of the Yucatán Peninsula is controlled by a karst system, where secondary porosity and high permeability promote the formation of large caverns, dissolution cavities, and channels conducting substantial quantities of water or epigean systems, known locally as cenotes or sink holes (Reddell 1981). The approximate number of cenotes in the Yucatán Peninsula has been estimated to range from 7000 to 8000 (Beddows et al. 2007), and cenotes account for an important share of the continental waters in the region. Cenotes exhibit important variability in regard to their light regime (Gaona Vizcayno et al. 1980, Schmitter-Soto et al. 2002). Those with good hydrological connections are filled with water that is quite transparent because rain water slowly filters through the karstic platform resulting in low amounts of suspended particles. Cenotes with poor hydraulic connection with the aquifer are characterized by turbid waters and very low transparency because of a high concentration of chlorophyll $a(\mathrm{Chl} a)$ mostly caused by the presence of diverse phytoplankton taxa (Schmitter-Soto et al. 2002) and sedimentation and dissolution of organic-matter particles and detritus (Beddows et al. 2007). In cenotes characterized by high amounts of dissolved organic C (DOC), UV-B radiation (280-315 nm) should be significantly reduced because these 2 variables are negatively correlated (Morris et al. 1995).

Cenotes are the main source of freshwater supply in the region, and they are important for tourism-related activities. They could be vulnerable to the action of climate- change variables, but to the best of our knowledge, no studies have addressed their potential impact (particularly of UVR and temperature) on natural phytoplankton communities. Indeed, most phytoplankton studies carried out in cenotes of the Yucatán Peninsula were descriptions of limnological characteristics or taxonomic studies (CervantesMartínez et al. 2002, Sánchez et al. 2002, Schmitter-Soto et al. 2002, Nava-Ruiz and Valadez 2012, Tavera et al. 2013, Valadez et al. 2013). To fill this gap, we chose 2 cenotes that fell within the range of biological and physical characteristics (as reported in previous descriptive studies carried out in the Yucatán Peninsula) but differed in their light regime. Leona Vicario is turbid, and Las Mojarras is clear. We used these cenotes as models to evaluate the combined effects of increased solar radiation and temperature on phytoplankton photosynthesis.

Many tropical species are already at their thermal tolerance limit (Banaszak and Lesser 2009), so we hypothesized that the combined effects of increasing UVR and temperature on phytoplankton photosynthesis would be synergistic. In addition, we expected the UVR-induced inhibition of photosynthesis to be higher in a more turbid cenote than in a clear one because acclimation mechanisms, triggered by the higher light conditions in clear cenotes, would enable phytoplankton to cope with UVR. To test our hypothesis, we collected water samples from the 2 study sites and exposed them to solar radiation with and without UVR and 2 temperatures: ambient $\left(25^{\circ} \mathrm{C}\right)$ and increased by $3^{\circ} \mathrm{C}$, as expected by the year 2100 (IPCC 2013). We followed the dynamics of photochemistry through a daily cycle under these projected conditions. Our results provide the first information about the potential vulnerability of phytoplankton communities from cenotes to the combined effect of increasing solar UVR and temperature.

\section{METHODS}

\section{Study area}

We conducted our study in 2 cenotes (sink holes) in the state of Quintana Roo in the Yucatán Peninsula, México (Fig. 1A, B). Leona Vicario (LV; lat $20^{\circ} 57^{\prime} 42^{\prime \prime} \mathrm{N}$, long $87^{\circ} 6^{\prime}$ $\left.27^{\prime \prime} \mathrm{W}\right)$ is used for recreational purposes, is cylindrical with a diameter of $123 \mathrm{~m}$ and a depth of $27 \mathrm{~m}$, and is $40 \mathrm{~km}$ from the shore of the Caribbean Sea. It is surrounded by reed beds and medium-height vegetation. The main economic activities in the area are agriculture and charcoal production (Forster et al. 2011), which have affected the water quality of the cenote. Las Mojarras (LM; lat $20^{\circ} 49^{\prime} 52^{\prime \prime} \mathrm{N}$, long $87^{\circ} 1^{\prime} 17^{\prime \prime} \mathrm{W}$ ) has the form of an elliptical cylinder, with a maximum diameter of $65 \mathrm{~m}$, a minimum diameter of $22 \mathrm{~m}$, and a depth of $16 \mathrm{~m}$, is $10 \mathrm{~km}$ from the shore of the Caribbean Sea, and is used exclusively for recreational purposes. Following Carlson's guidelines (Carlson 1977), both cenotes can be considered mesotrophic with $\mathrm{Chl} a$ values ranging 3 to $20 \mu \mathrm{g} / \mathrm{L}$ (see below). 


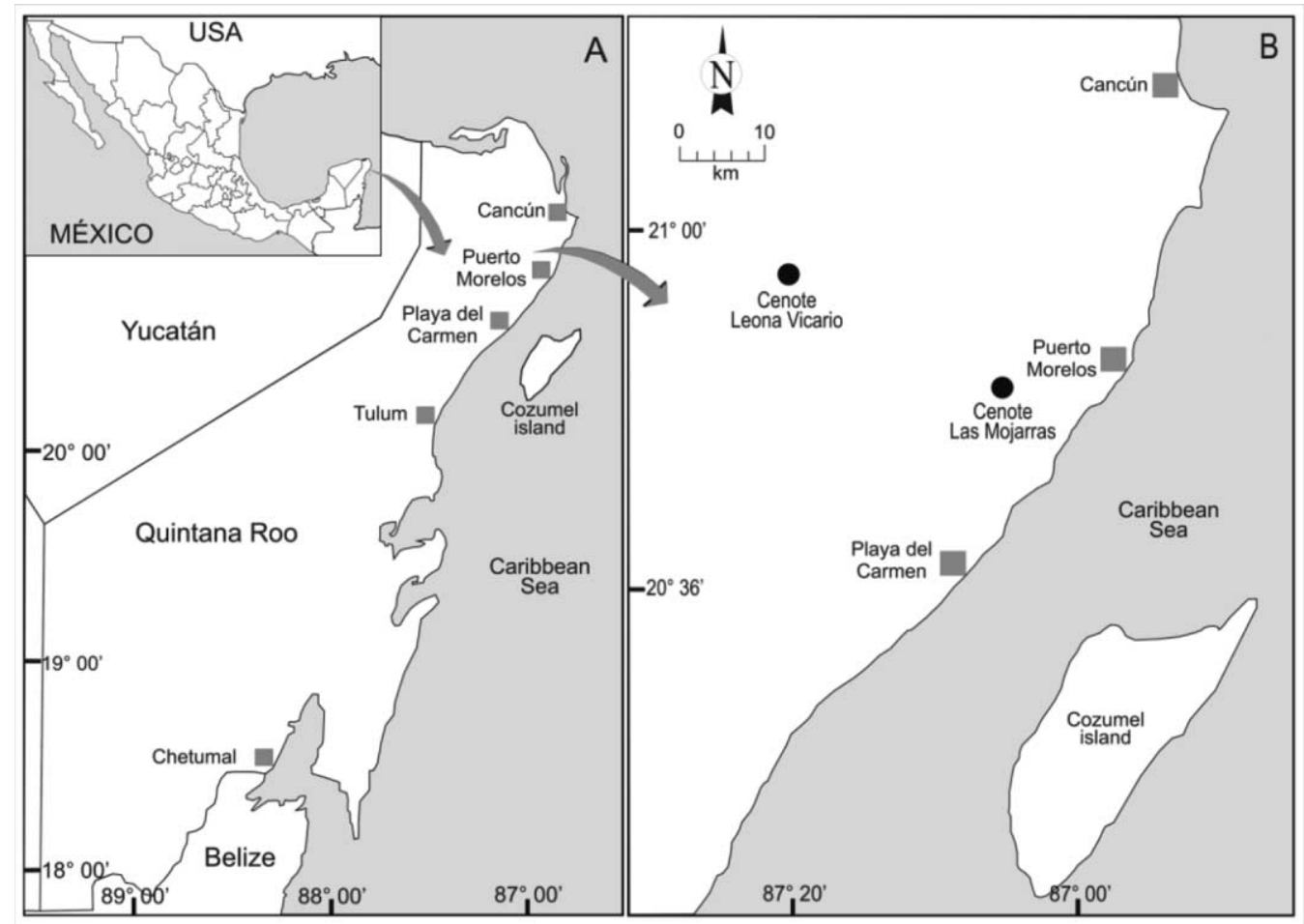

Figure 1. Map of the study area (A) indicating the sampling sites in cenotes Leona Vicario and Las Mojarras on the Yucatan Peninsula (B).

We carried out experiments to evaluate the photochemical efficiency of phytoplankton communities under UVR exposure and increased temperature on 22 December 2011 with samples taken from LV and on 26 December 2011 with samples from LM. On the day prior to experimentation, we measured the physical, optical, and biological characteristics of the water column (see below). We collected surface-water samples in acid-cleaned (1 N $\mathrm{HCl})$ opaque containers and immediately transported them to the Instituto de Ciencias del Mar y Limnología (ICMyL) in Puerto Morelos (40 min from the sampling sites) where we carried out the experiments, analyses, and measurements described below.

\section{Experimental procedure}

On arrival at ICMyL, we put phytoplankton samples into twelve 20-L UVR-transparent polypropylene bags (microcosms) under 2 radiation treatments $(n=3$ per radiation treatment): 1) samples receiving photosynthetically active radiation $(\mathrm{PAR})+\mathrm{UV}-\mathrm{A}+\mathrm{UV}-\mathrm{B}(\mathrm{PAB} ;>280 \mathrm{~nm})$ in uncovered containers, and 2 ) samples receiving only PAR $(\mathrm{P} ;>400 \mathrm{~nm})$, achieved by wrapping the bags with Ultraphan UV Opak Digefra film (Digefra, Munich, Germany). We measured the transmission characteristics of the filters and all materials used in our study, and they coincided with those previously reported by Buma et al. (2001) and Korbee
Peinado et al. (2004). We implemented 2 temperature treatments: 1) ambient $=25^{\circ} \mathrm{C}$ and 2) increased by 3 to $28^{\circ} \mathrm{C}$. We place a set of 6 microcosms ( $3 \mathrm{PAB}$ and $3 \mathrm{P}$ ) in each of 2 round water tanks (diameter $=1.60 \mathrm{~m}$, height $=45 \mathrm{~cm}$ ) in such a manner that only a thin layer of water covered them. Thus, the cells were exposed to the worst-case scenario for solar radiation, i.e., as if they were in the top layer of the water column. We maintained 1 tank at $25^{\circ} \mathrm{C}$, which was the mean surface temperature measured in the water column at the time of sampling (ambient temperature [control]). The temperature in the tank was maintained by a flow-through water system pumping water from $90 \mathrm{~m}$ depth. We maintained the other tank at $28^{\circ} \mathrm{C}$ (increased temperature) by pumping water from the reef lagoon from $4 \mathrm{~m}$ depth to tanks where it was heated by solar radiation to $28^{\circ} \mathrm{C}$ prior to its distribution. We monitored the temperature in both microcosms at 5-min intervals with data loggers (HOBO model water temperature Pro v2 Data Logger-U22-001; Onset Corporation, Bourne, Massachusetts) and several times daily with hand-held digital thermometers. To minimize the light gradient, we placed the microcosms in a horizontal plane, such that the surface area of the samples exposed was $\sim 50 \times 25 \mathrm{~cm}$ with a depth of $15 \mathrm{~cm}$. We manually shook the microcosms once an hour during the day to prevent cell sedimentation.

We measured daily cycles of photochemical activity (i.e., effective photochemical quantum yield $\left.\left[\Phi_{\mathrm{PSII}}\right]\right)$ by collect- 
ing samples every hour from each replicate in each treatment throughout the exposure period, which lasted from 0700 to $1800 \mathrm{~h}$. We made 1 measurement of the $\Phi_{\mathrm{PSII}}$ early in the morning on the following day to analyze the recovery capacity of samples during the night. We promoted gas exchange by injecting air with a syringe attached to plastic tubing inserted in the center of each microcosm. We also used this system for sample retrieval to avoid opening the microcosms.

\section{Analyses and measurements}

Solar radiation We monitored solar radiation continuously with a custom-made broad-band-filter radiometer that measures UV-B (280-315 nm), UV-A (315-400 nm), and PAR (400-700 $\mathrm{nm}$ ) every second, averages the data over a 1-min interval, and stores them in a computer. We used a solar calibration procedure to calibrate the instrument. We recorded vertical profiles of solar radiation in the water column of both cenotes at $1200 \mathrm{~h}$ with a USB diode array spectroradiometer (USB 2000; Ocean Optics, Dunedin, Florida) attached to a $10-\mathrm{m}$ fiber-optic cable and a cosine-corrected collector.

Physical and chemical characteristics of the water column We measured temperature, conductivity, and dissolved $\mathrm{O}_{2}$ with a multiparameter probe (model 556; Yellow Springs Instruments, Yellow Springs, Ohio). We obtained vertical profiles (1-m intervals) of these variables at $1200 \mathrm{~h}$ at each study site. We made a total of 50 measurements at each depth for each profile and used these values to calculate means and standard deviations for each depth.

Fluorescence measurements We recorded daily cycles of in vivo Chl $a$ fluorescence of phytoplankton with a portable pulse-amplitude-modulated fluorometer (Water-ED PAM; Walz GmbH, Effeltrich, Germany). We used a syringe to withdraw 3-mL samples hourly from each microcosm, and measured the fluorescence variables 6 times for each sample.

We calculated the effective photochemical quantum yield $\left(\Phi_{\text {PSII }}\right)$ (Genty et al. 1989$)$ as:

$$
\Phi_{\text {PSII }}=\Delta \mathrm{F}: \mathrm{F}_{\mathrm{m}}^{\prime}=\left(\mathrm{F}_{\mathrm{m}}^{\prime}-\mathrm{F}_{\mathrm{t}}\right): \mathrm{F}_{\mathrm{m}}^{\prime}
$$

where $\mathrm{F}_{\mathrm{m}}^{\prime}$ is the instantaneous maximum intensity of $\mathrm{Chl} a$ fluorescence in an irradiated cell induced by a saturating pulse $\left(\sim 5300 \mu \mathrm{mol}\right.$ photons $\mathrm{m}^{-2} \mathrm{~s}^{-1}$ in $\left.0.8 \mathrm{~s}\right)$ in the presence of an actinic light, and $F_{t}$ is the steady-state fluorescence induced by the actinic light in light-adapted cells.

We calculated inhibition rates of $\Phi_{\mathrm{PSII}}(k, / \mathrm{min})$ by applying an exponential decay function fit to the $\Phi_{\text {PSII }}$ data between the initial time (early morning) and local noon, as:

$$
\Phi_{\text {PSII }}=\mathrm{Ae}^{-k \mathrm{t}}
$$

We calculated recovery rates of $\Phi_{\text {PSII }}(r, / \mathrm{min})$ with the $\Phi_{\text {PSII }}$ data between the local noon and the last data point measured in the evening, as:

$$
\Phi_{\text {PSII }}=\mathrm{Ae}^{r \mathrm{t}}
$$

where $\Phi_{\text {PSII }}$ is the quantum yield of PSII, A is a constant, $k$ and $r$ represent the inhibition and recovery rates, respectively, and $\mathrm{t}$ is the time. The $R^{2}$ of all fits was $>0.9$.

Taxonomic analyses, $C h l$ a, and concentrations of UVabsorbing compound We collected samples for identification and enumeration of phytoplankton at the start of the experiments and placed them in 125-mL brown-glass bottles and fixed them with buffered formalin (final concentration $0.4 \%$ of formaldehyde in the sample). We allowed 50 -mL subsamples to settle for $48 \mathrm{~h}$ in an Utermöhl chamber (Hydro-Bios GmbH, Kiel, Germany), and identified and counted species with the aid of an inverted microscope (Zeiss Axiovert 40 CFL; Carl Zeiss, Thornwood, New York) following the technique described by Villafañe and Reid (1995). The biovolumes of the phytoplankton species were estimated by comparing and adjusting their shape to known geometric forms according to Hillebrand et al. (1999) and by measuring the main cell dimensions of $\geq 30$ cells/species.

We measured Chl $a$ concentration on the sampling day and at the end of the experiments from each replicate by filtering 800 to $1500 \mathrm{~mL}$ or 400 to $700 \mathrm{~mL}$ of sample (LV and LM, respectively) onto a Whatman GF/F filter (25 mm; Whatman, Maidstone, UK) and extracting the photosynthetic pigments and UV-absorbing compounds in absolute methanol (Holm-Hansen and Riemann 1978). We ran a scan between 250 and $750 \mathrm{~nm}$ with the Ocean Optics USB2000, and calculated Chl a concentration with the equations of Porra (2002). The presence of UV-absorbing compounds was estimated by the peak at $337 \mathrm{~nm}$ (Helbling et al. 1996).

Statistical and data analysis For each cenote, we used a 2-way analysis of variance (ANOVA) test to assess effects of interactions between irradiance and temperature (Zar 1999) on inhibition and recovery rates of $\Phi_{\text {PSII }}$. We used a 1-way repeated measures ( $\mathrm{rm})$ ANOVA to test for differences in $\Phi_{\text {PSII }}$ among radiation treatments within the same temperature treatment during the daily cycles. In both cases, we used a 95\% confidence limit and 1 degree of freedom. We conducted exposure treatments in triplicate, so we report data as means and standard deviations. 
We used error propagation to calculate the variance of the UVR and temperature effects.

\section{RESULTS}

\section{Optical, physical, and biological characteristics}

Attenuation of solar radiation in the water column was higher at LV (Fig. 2A) than at LM (Fig. 2B). For example, UVR wavelengths disappeared $(<0.1 \%$ of surface irradiance) at $<0.75 \mathrm{~m}$ in LV and at $\sim 2 \mathrm{~m}$ in LM. The attenuation coefficients for UVR $\left(k_{\mathrm{UVR}}\right)$ were $>14$ and $>4 / \mathrm{m}$ for $\mathrm{LV}$ and LM, respectively. The PAR attenuation coefficients $\left(k_{\text {PAR }}\right)$ were 1.4 and $0.6 / \mathrm{m}$ for LV and $L M$, respectively.

The water columns of both cenotes were slightly thermally stratified with a continuous decrease from the surface value until 4 to $6 \mathrm{~m}$ (Fig. 3). Surface temperature at $\mathrm{LV}$ was $\sim 24.6^{\circ} \mathrm{C}$, and reached a relatively constant value of $23.3^{\circ} \mathrm{C}$ below 4 to $6 \mathrm{~m}$ until $16 \mathrm{~m}$. The surface temperature was higher at $\mathrm{LM}\left(25.3^{\circ} \mathrm{C}\right)$ than at $\mathrm{LV}$ and decreased by $1^{\circ} \mathrm{C}$ toward $6 \mathrm{~m}$, below which it stabilized. Vertical profiles of conductivity and dissolved $\mathrm{O}_{2}$ (data not shown)

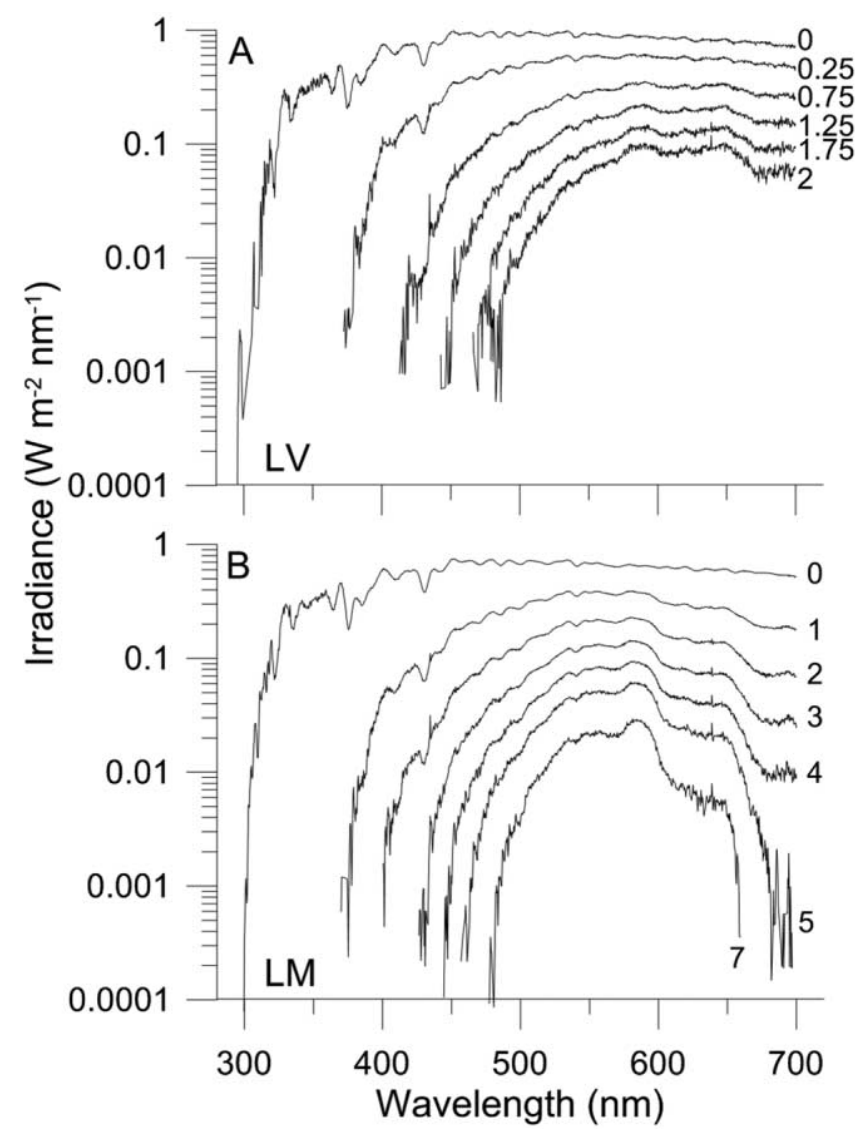

Figure 2. Underwater spectra of downwelling irradiance in cenotes Leona Vicario (LV) on 22 December 2011 (A) and Las Mojarras (LM) on 26 December 2011 (B). Numbers indicate the depths in meters where the spectra were obtained.

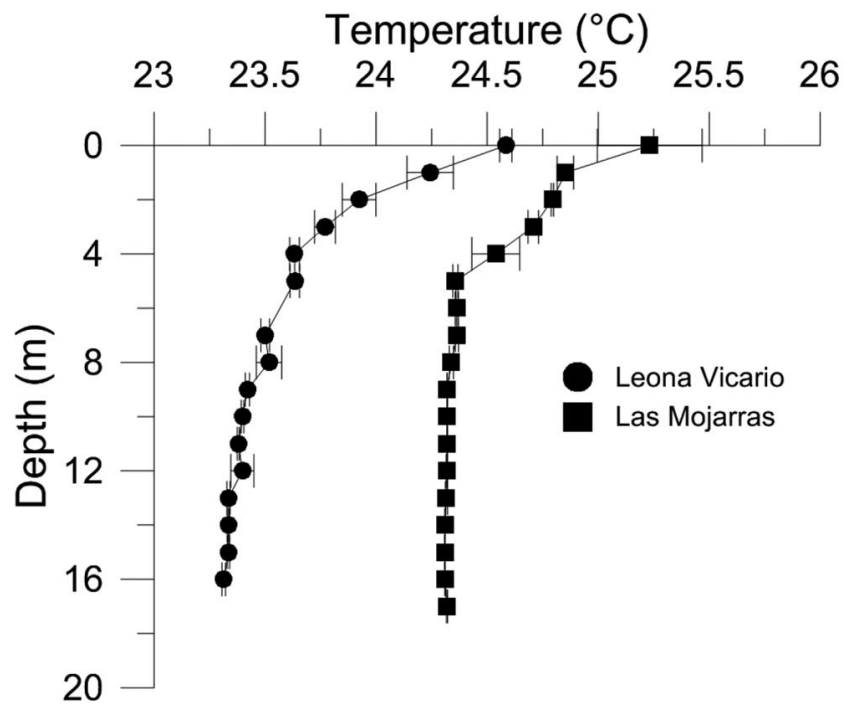

Figure 3. Temperature as a function of depth in the cenotes Leona Vicario and Las Mojarras.

at both cenotes showed little variation with depth. Salinity values for the upper $16 \mathrm{~m}$ were $0.29 \pm 0.0006$ and $0.59 \pm$ 0.0045 and $\mathrm{O}_{2}$ concentrations in the water column were $8.49 \pm 0.007$ and $8.19 \pm 0.005 \mathrm{mg} / \mathrm{L}$ at LV and LM, respectively.

Cyanobacteria numerically dominated the phytoplankton community in both cenotes (62 and 92\% at LV and LM, respectively; Fig. 4A, B), but Bacillariophyta and Cryptophyta species dominated in terms of biovolume (Fig. 4C, D). The most abundant species in LV were Chroococcus minor (Cyanobacteria), Tetrastrum komarekii (Chlorophyta), Cryptomonas curvata (Cryptophyta), and Encyonopsis cesatii (Bacillariophyta), whereas the most representative Cyanobacteria species in LM were Pseudanabaena limnetica and, to a lesser extent, Aphanocapsa delicatissima and Epigloeosphaera glebulenta. The Chlorophyta, represented by Monoraphidium irregulare, and the Bacillariophyta, represented by Brachysira microcephala and Encyonopsis cesatii, followed in abundance. The Cryptophyta and Dinophyta had almost negligible abundances. The bulk of the biovolume in LV consisted of Bacillariophyta and Cryptophyta species, whereas the largest contribution in LM was from the Bacillariophyta. The Bacillariophyta species in LM were smaller $\left(330 \mu \mathrm{m}^{3}\right)$ than those in LV $\left(524 \mu \mathrm{m}^{3}\right)$, but the Cryptophyta were much larger $\left(177 \mu \mathrm{m}^{3}\right.$ and $1139 \mu \mathrm{m}^{3}$ in LV and $\mathrm{LM}$, respectively).

\section{Chl $a$ and photochemical responses}

Solar radiation and temperature had variable effects on Chl $a$ concentration depending on the cenote (Fig. 5A, B). Initial Chl $a$ concentration in LV was relatively low at $\sim 3 \mu \mathrm{g} / \mathrm{L}$ (Fig. $5 \mathrm{~A}$ ). On a short-term basis (i.e., over the 1-d light cycle experiment), temperature did not exert 


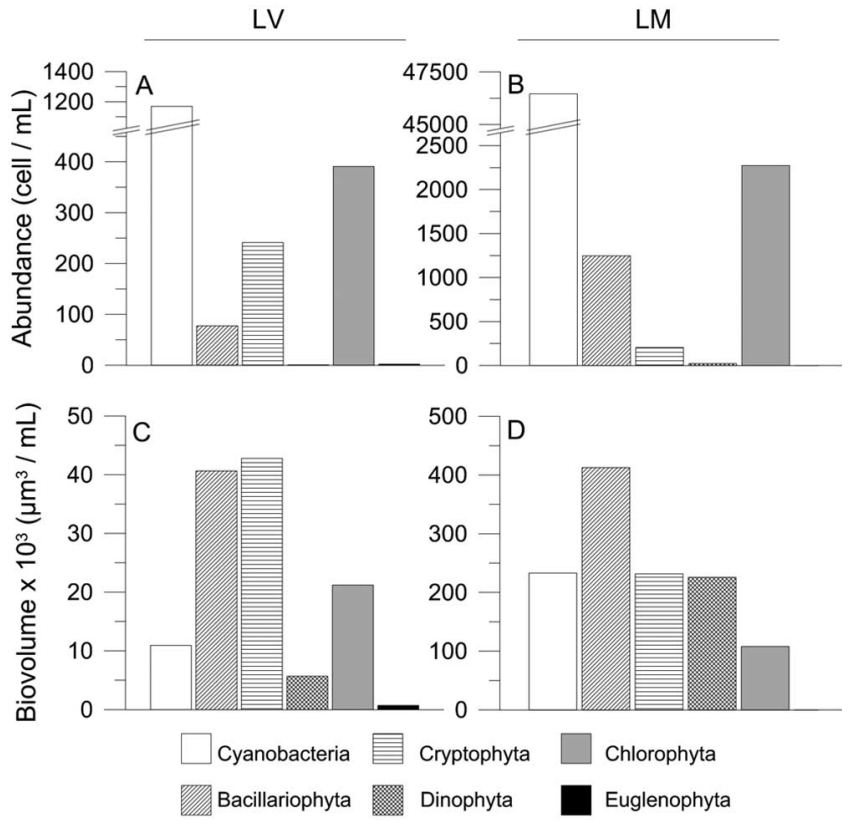

Figure 4. Abundance (A, B) and biovolume (C, D) of phyla in the phytoplankton communities of the cenotes Leona Vicario (LV) (A, C) and Las Mojarras (LM) (B, D).

an effect on Chl $a$ concentration in samples from $\mathrm{LV}$ (Fig. 5A) incubated in the absence of UVR when compared to the beginning $\left(\mathrm{t}_{0}\right)$ of the incubation. However, when exposed to UVR, Chl $a$ concentration decreased significantly $(p<0.05)$ at both 25 and $28^{\circ} \mathrm{C}$ relative to the concentration at $t_{0}$. Therefore, only exposure to UVR caused a significant decrease of Chl $a$ in this cenote. The initial concentration of Chl $a$ in LM (Fig. 5B) was $9.3 \mu \mathrm{g} / \mathrm{L}$, i.e., $\sim 3 \times$ higher than that in LV. After exposing the cells from $\mathrm{LM}$ for $1 \mathrm{~d}$ to the solar radiation and temperature treatments, Chl a concentration decreased significantly relative to $t_{0}$ in all 4 treatments. Samples incubated under the P treatment at high temperature were the least affected compared to the other treatments. We did not find evidence of UV-absorbing compounds in LV, but a small shoulder (between 310-360 nm) was present in the spectra from LM (data not shown).

Solar UVR induced a significant decrease in the $\Phi_{\text {PSII }}$ of the phytoplankton community from both cenotes. In $L V, \Phi_{\text {PSII }}$ showed a characteristic response with a typical midday depression during this relatively cloudy day (but with high UV-B irradiances $\sim 1 \mathrm{~W} / \mathrm{m}^{2}$ at local noon) (Fig. 6A). The highest $\Phi_{\text {PSII }}$ values $(0.35-0.4)$ were measured at the beginning of the exposure to natural solar radiation (early morning) and decreased toward noon. A partial recovery was observed during the afternoon once the radiation levels decreased, and maximal $\Phi_{\mathrm{PSII}}$ values reached 0.16 to 0.23 . A slightly higher recovery was observed in all samples during the night, when $\Phi_{\mathrm{PSII}}$ values reached 0.21 to 0.28 , which were $\sim 67 \%$ of the initial $t_{0}$ values (data not shown). In LM, measurements of $\Phi_{\text {PSII }}$ over a 1-d cycle (Fig. 6B) were made on a slightly cloudy day, with maximal UV-B values of $1.2 \mathrm{~W} / \mathrm{m}^{2}$ at local noon. As expected, the lowest values of $\Phi_{\text {PSII }}$ were measured during the high-radiation hours (around local noon), and a characteristic increase was observed during the afternoon hours. At noon, samples receiving only PAR under ambient temperature had the highest values of $\Phi_{\mathrm{PSII}}$ relative to the other 3 treatments, whereas the samples that presented the lowest $\Phi_{\mathrm{PSII}}$ values were those exposed to UVR at elevated temperatures. Recovery was similar at the end of the light day and almost complete during the night ( $\sim 90 \%$ of the $t_{0}$ values) in all 4 treatments.

Inhibition $(k)$ and recovery $(r)$ rates of $\Phi_{\text {PSII }}$ were used to compare the responses of both phytoplankton communities (Fig. 7A, B). UVR had significant effects on $k$ in the 2 cenotes, with higher absolute values of $k$ in samples receiving UVR compared to those receiving only PAR (Fig. 7A). The UVR-induced effect on $\Phi_{\text {PSII }}$ at ambient temperature (i.e., comparing $k \mathrm{~s}$ in $\mathrm{PAB}$ and $\mathrm{P}$ treatments at $25^{\circ} \mathrm{C}$ ) in samples from LV was $71 \%$ (Fig. $7 \mathrm{~B}$ ), whereas the effect of temperature resulted in an inhibition of $44 \%$

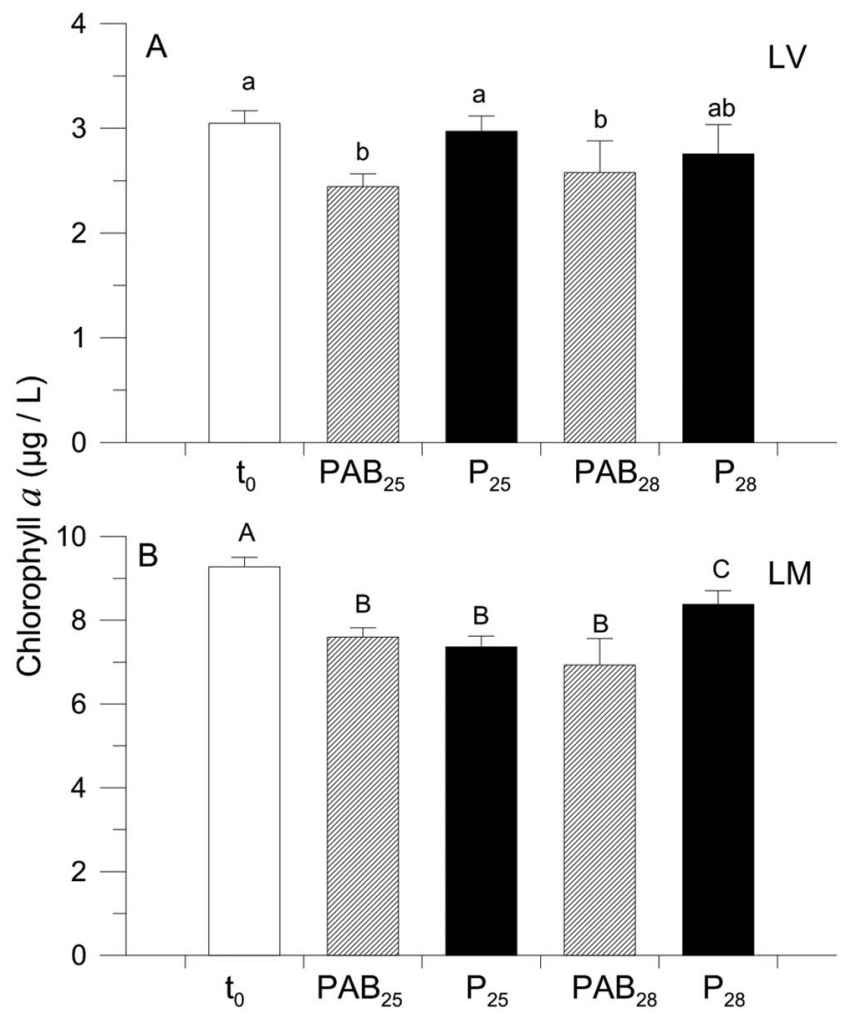

Figure 5. Mean ( \pm 1 SD) chlorophyll $a$ content in samples from the cenotes Leona Vicario (LV) (A) and Las Mojarras (LM) (B) at the time samples were collected $\left(t_{0}\right)$ and after $1 \mathrm{~d}$ of exposure to each of 4 ultraviolet radiation (UVR) (photosynthetically active radiation $[\mathrm{P}]$ only vs $\mathrm{P}+\mathrm{UV}-\mathrm{A}+\mathrm{UV}-\mathrm{B}$ $[\mathrm{PAB}]) \times$ temperature $\left(25\right.$ vs $\left.28^{\circ} \mathrm{C}\right)$ treatments. Bars with the same letters are not significantly different $(p>0.05)$. Bar fills are as in Fig. 4. 


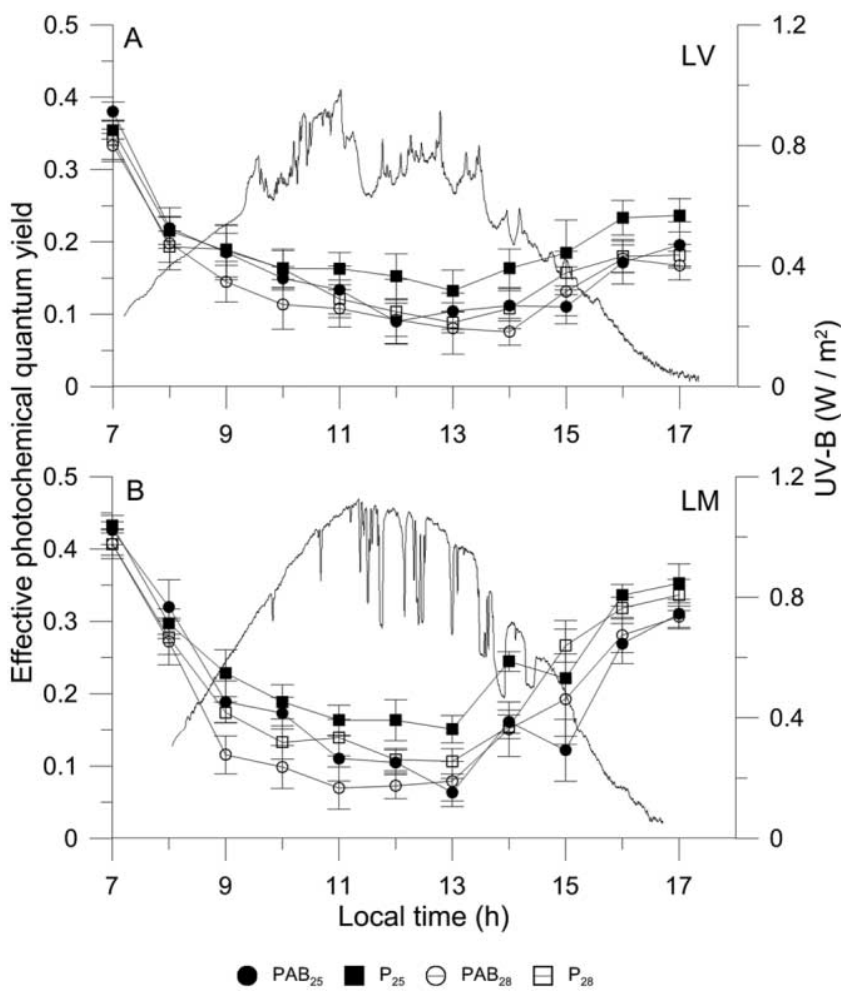

Figure 6. Mean $( \pm 1 \mathrm{SD})$ effective photochemical quantum yield $\left(\Phi_{\mathrm{PSII}}\right)$ of phytoplankton communities from the cenotes Leona Vicario (LV) (A) and Las Mojarras (LM) (B) during daylight exposure under the 4 ultraviolet radiation (UVR) (photosynthetically active radiation $[\mathrm{P}]$ only vs $\mathrm{P}+\mathrm{UV}-\mathrm{A}+\mathrm{UV}-\mathrm{B}$ $[\mathrm{PAB}]) \times$ temperature $\left(25 \mathrm{vs} 28^{\circ} \mathrm{C}\right)$ treatments. The continuous line indicates the irradiance for UV-B during the daily cycle.

(i.e., comparing $k s$ in $\mathrm{P}$ treatments at 25 and $28^{\circ} \mathrm{C}$ ). The sum of the UVR and temperature effects in LV indicated an inhibition of $115 \%$. However, UVR and temperature interacted $(p<0.05)$, and the combined effects (i.e., comparing $k$ in $\mathrm{PAB}$ at $28^{\circ} \mathrm{C}$ with $k$ in $\mathrm{P}$ at $25^{\circ} \mathrm{C}$ ), resulted in a smaller inhibition of $\Phi_{\text {PSII }}(63 \%)$ than the sum of the individual variable effects (Fig. 7B). Thus, for LV samples, an increase in temperature acted antagonistically with UVR to reduce its negative effects on $\Phi_{\text {PSII }}$. The lowest $r$-values were measured in samples receiving only PAR at ambient temperature, and $r$-values did not differ among the other treatments.

UVR and temperature also interacted to affect $k$ in samples from LM $(p<0.05)$. The UVR effect on $k$ at ambient temperature was significant and inhibited $\Phi_{\text {PSII }}$ by $82 \%$ (Fig. 7B). Temperature also significantly affected the LM phytoplankton community. In the P treatments, the inhibition of $\Phi_{\text {PSII }}$ caused by elevated temperature was $52 \%$ relative to ambient temperature. In LM, the UVR and temperature interaction was synergistic because the combined inhibition of $\Phi_{\text {PSII }}$ (i.e., comparing $k$ in PAB at $28^{\circ} \mathrm{C}$ with $k$ in $\mathrm{P}$ at $25^{\circ} \mathrm{C}$ ) was higher $(172 \%)$ than the sum of the indi- vidual effects (134\%). Overall, absolute values of $k$ and $r$ were significantly higher for phytoplankton from LM than from LV.

\section{DISCUSSION}

The phytoplankton communities chosen as representative of 2 underwater light radiation conditions from cenotes responded differently when exposed to increased solar radiation and temperature levels that are expected in the near future. Our use of microcosms prevented us from mimicking other abiotic and biotic factors that might have affected the observed responses, e.g., turbulent motion, grazing, etc. However, the approach gives a good approximation of how phytoplankton communities might respond in a short-term scale to projected UVR and temperature conditions. UVR and temperature interacted in markedly different ways when assessing PSII photochemical responses of phytoplankton from these 2 differing cenotes. In particular, the interaction between UVR and temperature was antagonistic in LV and synergistic in LM. The LV responses led us to partially reject our working hypothesis.

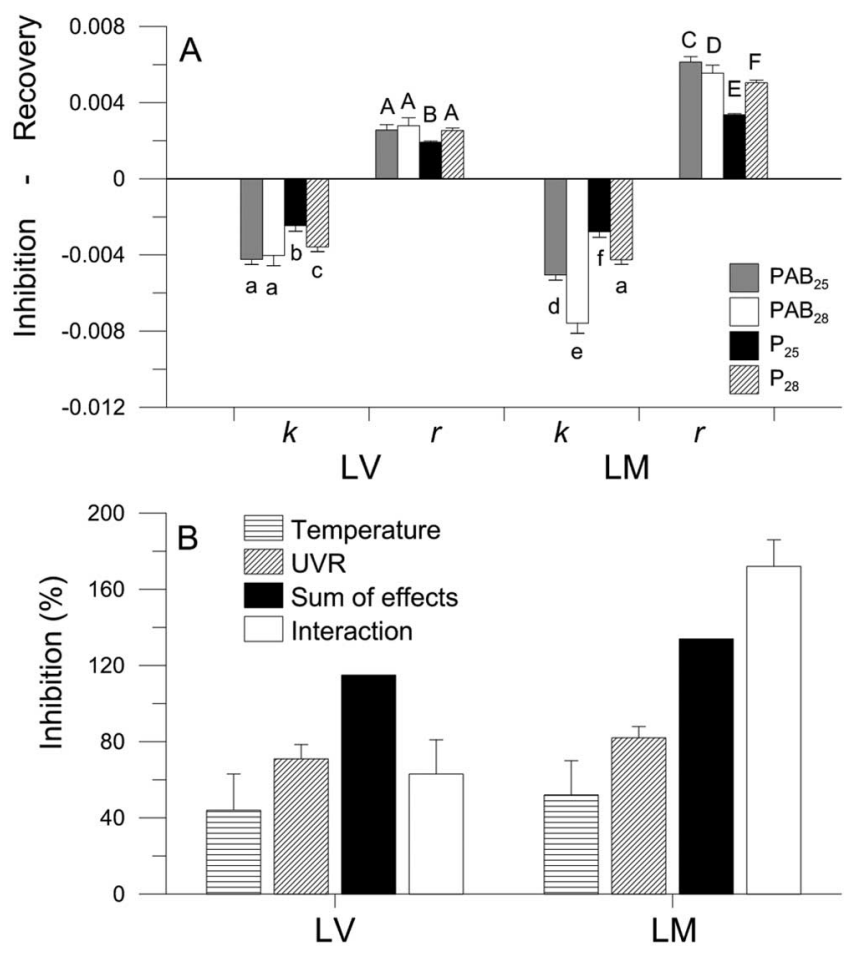

Figure 7. Mean $( \pm 1$ SD) inhibition $(k)$ and recovery rates $(r)$ (A) and \% inhibition caused by temperature $\left(25\right.$ vs $\left.28^{\circ} \mathrm{C}\right)$ and ultraviolet radiation (UVR) (photosynthetically active radiation $[\mathrm{P}]$ only vs $\mathrm{P}+\mathrm{UV}-\mathrm{A}+\mathrm{UV}-\mathrm{B}[\mathrm{PAB}])$ and their combinations (B) of the effective photochemical quantum yields $\left(\Phi_{\text {PSII }}\right)$ of phytoplankton communities from the cenotes Leona Vicario (LV) and Las Mojarras (LM) during daylight exposure. Bars with the same letters are not significantly different $(p>0.05)$. 
Several factors might account for the differential responses to these global-change variables. These include the limnological conditions of the aquatic system, penetration of solar radiation, the differences in the size structure and taxonomic composition of the community, the variability in metabolic responses under increased temperature levels, and the type and effectiveness of the strategies used by the organisms to cope with solar UVR. In the following paragraphs, we will analyze some of these factors that could help to explain the photochemical responses of the phytoplankton communities studied.

The cenotes of the Yucatán Peninsula share common characteristics, especially with regard to their origin and morphology (Gaona Vizcayno et al. 1980), but they are characterized by wide variation in the level and type of abiotic and biotic factors that affect them (Schmitter-Soto et al. 2002). In particular, previous investigators (CervantesMartínez et al. 2002, Camargo-Guerra et al. 2013) have measured important differences in the penetration of solar radiation as estimated by Secchi-disk depth, which ranged from 1.5 to $\sim 10 \mathrm{~m}$, corresponding to $k_{\text {PAR }}$ of $\sim 1.13$ and $0.17 / \mathrm{m}$, respectively (Margalef 1983). In our study, penetration of solar radiation in the water column was greater in LM than in LV (Fig. 2A, B), and euphotic zones were $7.7 \mathrm{~m}$ and $3.3 \mathrm{~m}$ in depth, respectively. The $k_{\mathrm{PAR}}$ values in these 2 cenotes $(0.6$ and $1.4 / \mathrm{m})$ were higher than those measured in other karstic systems; i.e., lakes of the Ruidera National Park (0.2-0.4/m; VEV, unpublished data) or in Lake Enol (0.34/m; Helbling et al. 2013) in the Iberian Peninsula. Thus, comparatively, these 2 cenotes are relatively turbid systems. Moreover, we observed strong attenuation of solar UVR wavelengths in both cenotes. Dissolved organic matter (DOM) probably plays an important role in decreasing the penetration of solar UVR in the water column, as seen in other studies all over the world (Osburn and Morris 2003). However, attenuation of solar radiation seems to occur by different processes. In LV, solar radiation was mostly attenuated by the high amounts of dissolved and particulate material possibly derived from the nearby urban activities (including waste water) from the city of 13,000 inhabitants and ash from the production of charcoal in the region. In LM, eutrophication processes might have taken place, mainly because of high DOM input from the aquifer or bioturbation effects from tourism (Kauffer-Michel and Villanueva-Aguilar 2011). The discharge of subterranean fresh water has been identified as an important source of nutrients to many coastal ecosystems (McComb et al. 1993, Smith 2003) like LM, which is close to the shoreline. This source of nutrients might explain the greater abundance of phytoplankton in LM than in LV (evaluated by microscopic analysis [Fig. 4A, B] and Chl $a$ [Fig. 5A, B]).

Moreover, the degree of stratification and the depth of the epilimnion must be considered because, together with the incident irradiance, they are the variables determining the amount of solar energy received by any particular phytoplankton cell. Both cenotes had weak stratification at $\sim 4 \mathrm{~m}$, with temperature decreasing continuously $\sim 1^{\circ} \mathrm{C}$ in the upper part of the water column (Fig. 3A, B). Therefore, cells in this layer might have received relatively higher radiation levels. However, vertical profiles of conductivity and $\mathrm{O}_{2}$ (not shown) suggested a rather well mixed water column. In any case, these stratification processes seem to be a common feature, given the calm weather conditions that prevail in the area, as seen in previous studies conducted in the Aguada X'caamal (Hodell et al. 2005).

The differences in the penetration of solar radiation may have important consequences for the acclimation and responses of the natural phytoplankton communities. One potential way to analyze the acclimation of phytoplankton cells to solar radiation is through the amount of Chl a/ cell, with cells acclimated to low irradiances having more Chl $a /$ cell or /biovolume than light-acclimated ones (Falkowski and Owens 1980). As expected from our data, phytoplankton from LM (with relatively higher penetration of solar radiation) had 9 and $3 \times$ less $\mathrm{Chl} a /$ cell (based either on abundance or biovolume, respectively) than the phytoplankton cells from LV. Therefore, cells from LM were comparatively light-acclimated. The differential acclimation to solar radiation also is related to the different taxonomic composition among sites, as has been observed in other study sites (Villafañe et al. 2004).

Previous studies on phytoplankton taxonomy of cenotes have included a list of almost 150 species (Schmitter-Soto et al. 2002), with Chlorophyta, Cyanobacteria, and Bacillariophyta being dominant. In agreement with these previous studies, we found in both LV and LM that the dominant taxonomic group was Cyanobacteria (Fig. 4A, B). However, the size distributions differed between sites, with an overall smaller cell size in LV $\left(1300 \mu^{3}\right)$ than in LM $\left(2450 \mu^{3}\right.$ ) (Fig. 4C, D). However, in some taxa (i.e., Cyanobacteria and Bacillariophyta), the cells were larger in LV, but because of their relatively low abundance (as compared to LM) their contribution to the overall community size was small (Fig. 4A-D). In terms of acclimation, these differential size distributions are important because small cells in a relatively opaque environment (such as in LV) can better use the available solar radiation because of their higher surface-to-volume ratio (Falkowski and Owens 1980). Size-related responses to solar radiation have been well documented in prior studies (Karentz et al. 1991, Helbling et al. 2001).

In previous studies, light history and acclimation to high solar radiation resulted in a better fitness of cells (Helbling et al. 1992). Acclimation to high solar levels is associated with several processes, which include synthesis of UVabsorbing compounds (Banaszak 2003), induction of the xanthophyll cycle (Van de Poll and Buma 2009), and fast 
repair mechanisms related to the D1 protein (Bouchard et al. 2006). UV-absorbing compounds did not seem to be an effective mechanism of photoprotection in these communities, probably because of the low penetration of solar radiation, since the synthesis of these compounds increase with high radiation levels (Helbling et al. 1996). However, this relatively small amount of UV-absorbing compounds, as compared with previously published spectra from other natural environments (Ayoub et al. 2012), is not enough to account for the differences in responses among the phytoplankton communities between cenotes. One would expect the presence of UV-absorbing compounds to result in lower levels of inhibition, but both communities had a similar decrease in $\Phi_{\text {PSII }}$ caused by UVR; i.e., 71 and $81 \%$ for LV and LM, respectively, at ambient temperature (Fig. 7A, B).

Research focused on evaluating the combined effects of global-change variables on diverse metabolic processes of phytoplankton, in terms of the antagonistic or synergistic interactions that take place among them, has been undertaken only recently (Christensen et al. 2006, Helbling et al. 2013, Villafañe et al. 2013). Universal responses clearly do not exist, and variability among and within ecosystems is common. These variables interact differentially and responses depend on light history, species composition, and the ability of the species to acclimate to the particular experimental conditions used. The antagonistic relationship between UVR and temperature, as observed in our experiments carried out with LV samples (Fig. 7B), has been well established (Sobrino and Neale 2007, Halac et al. 2010, Villafañe et al. 2013). The counteracting effect of warming over UVR is explained by increased metabolic rates at higher temperatures, especially of enzymes, such as Rubisco, that are related to the photosynthetic process (Helbling et al. 2011). On the other hand, synergism between these 2 variables, as found with our samples from LM, also has been observed, especially in tropical systems (Banaszak et al. 2003, Halac et al. 2013) because species are already at their thermal tolerance limit. Under these conditions, results of previous studies (Paerl 1988, Paerl and Huisman 2008, Paul 2008) suggested that an increase in surface-water temperatures could play a role in the proliferation of Cyanobacteria. Thus, the thermal tolerance could be one of the factors that drove the Cyanobacterial dominance in LM. Given the Cyanobacteria species found in our study (Chroococcus minutus and Pseudanabaena limnetica), the assemblages of Cyanobacteria in these water bodies could have negative effects, such as a loss of diversity and blooms of toxic microalgae, on ecosystem structure. However, algal blooms are complex events, and typically are not caused by a single environmental driver.

Overall, the effects of these differential interactions among climate-change-related variables on phytoplankton from cenotes of the Yucatán Peninsula point to a complex relationship between biotic and abiotic variables that will affect the response of phytoplankton and freshwater quality because of the dominance of Cyanobacteria. The size distribution of the phytoplankton community seems to be an important variable determining the interaction between UVR and temperature because of the faster response of small than large cells to environmental changes, as has been shown in other environments (Finkel et al. 2010). Future use of cenotes and the potential changes in the penetration of solar radiation will further complicate this view and the ability of phytoplankton to cope with environmental stressors.

\section{ACKN OWLEDGEMENTS}

We thank Associate Editor Robert Hall and an anonymous referee for comments and suggestions that helped us to improve this manuscript. We thank D. Martínez and O. Helbling for their help during the experiments. This work was supported by Ministerio de Ciencia, Tecnología e Innovación Productiva (MINCyT, Argentina, Project MX/09/13) - Consejo Nacional de Ciencia y Tecnología (CONACyT, México, Projects J010.191 and B330.332), Agencia Nacional de Promoción Científica y Tecnológica (ANPCyT, Argentina, PICT2012-0271), Consejo Nacional de Investigaciones Científicas y Técnicas (CONICET, Argentina, PIP N $\left.{ }^{\circ} 112-201001-00228\right)$, the Instituto de Ciencias del Mar y Limnología, Universidad Nacional Autónoma de México, Comisión Nacional para el Conocimiento y Uso de la Biodiversidad (CONABIO-JF012, México) and Fundación Playa Unión. This is contribution 154 of the Estación de Fotobiología Playa Unión.

\section{LITERATURE CITED}

Ayoub, L. M., P. Hallock, P. G. Coble, and S. S. Bell. 2012. MAA-like absorbing substances in Florida Keys phytoplankton vary with distance from shore and CDOM: implications for coral reefs. Journal of Experimental Marine Biology and Ecology 420/421:91-98.

Ballaré, C. L., M. M. Caldwell, S. D. Flint, S. A. Robinson, and J. F. Bornman. 2011. Effects of solar ultraviolet radiation on terrestrial ecosystems. Patterns, mechanisms, and interactions with climate change. Photochemical and Photobiological Sciences 10:226-241.

Banaszak, A. T. 2003. Photoprotective physiological and biochemical responses of aquatic organisms. Pages 329-356 in E. W. Helbling and H. E. Zagarese (editors). UV effects in aquatic organisms and ecosystems. Royal Society of Chemistry, Cambridge, UK.

Banaszak, A. T., B. N. Ayala-Schiaffino, A. Rodríguez-Román, S. Enríquez, and R. Iglesias-Prieto. 2003. Response of Millepora alcicornis (Milleporina: Milleporidae) to two bleaching events at Puerto Morelos reef, Mexican Caribbean. Revista Biologia Tropical 51:57-66.

Banaszak, A. T., and M. P. Lesser. 2009. Effects of solar ultraviolet radiation on coral reef organisms. Photochemical and Photobiological Sciences 8:1276-1294.

Beardall, J., and J. A. Raven. 2004. The potential effects of global climate change on microalgal photosynthesis, growth and ecology. Phycologia 43:26-40. 
Beddows, P., P. Blanchon, E. Escobar, and O. Torres-Talamante. 2007. Los cenotes de la península de Yucatán. Arqueología Mexicana 83:31-35.

Bouchard, J. N., S. Roy, and D. A. Campbell. 2006. UVB effects on the photosystem II-D1 protein of phytoplankton and natural phytoplankton communities. Photochemistry and Photobiology 82:936-951.

Buma, A. G. J., E. W. Helbling, M. K. de Boer, and V. E. Villafañe. 2001. Patterns of DNA damage and photoinhibition in temperate South-Atlantic picophytoplankton exposed to solar ultraviolet radiation. Journal of Photochemistry and Photobiology B: Biology 62:9-18.

Camargo-Guerra, T., L. H. Escalera-Vázquez, and L. Zambrano. 2013. Fish community structure dynamics in cenotes of the Biosphere Reserve of Sian Ka'an, Yucatán Peninsula, Mexico. Revista Mexicana de Biodiversidad 84:901-911.

Carlson, R. 1977. A trophic state index for lakes. Limnology and Oceanography 22:361-368.

Cervantes-Martínez, A., M. Elías-Gutiérrez, and E. SuárezMorales. 2002. Limnological and morphometrical data of eight karstic systems 'cenotes' of the Yucatan Peninsula, Mexico, during the dry season (February-May, 2001). Hydrobiologia 482:167-177.

Christensen, M. R., M. D. Graham, R. D. Vinebrooke, D. L. Findlay, M. J. Paterson, and M. A. Turner. 2006. Multiple anthropogenic stressors cause ecological surprises in boreal lakes. Global Change Biology 12:2316-2322.

Dunne, R. P. 2010. Synergy or antagonism-interactions between stressors on coral reefs. Coral Reefs 29:145-152.

Falkowski, P. G., and T. G. Owens. 1980. Light-shade adaptation, two strategies in marine phytoplankton. Plant Physiology 66:592-595.

Finkel, Z. V., J. Beardall, K. J. Flynn, A. Quigg, A. V. Rees, and J. A. Raven. 2010. Phytoplankton in a changing world: cell size and elemental stoichiometry. Journal of Plankton Research 32:119137.

Forster, R., N. Armijo-Canto, and L. A. Argüelles-Suárez. 2011. Recursos forestales. Pages 140-150 in C. Pozo, N. ArmijoCanto, and S. Calmé (editors). Riqueza biológica de Quintana Roo. Un análisis para su conservación. Gobierno del Estado de Quintana Roo y Programa de Pequeñas Donaciones, México D. F., México. (Available from: http://www.biodiversidad.gob .mx/region/EEB/pdf/QuintanaRoo/TOMO_1/3_Capitulo_baja .pdf)

Gaona Vizcayno, S., T. Gordillo de Anda, and M. Villasuso Pino. 1980. Cenotes, karst característico en mecanismos de formación. Revista Mexicana de Ciencias Geológicas 4:32-36.

Genty, B. E., J. M. Briantais, and N. R. Baker. 1989. Relative quantum efficiencies of the two photosystems of leaves in photorespiratory and non-photorespiratory conditions. Plant Physiology and Biochemistry 28:1-10.

Häder, D.-P., E. W. Helbling, C. E. Williamson, and R. C. Worrest. 2011. Effects of UV radiation on aquatic ecosystems and interactions with climate change. Photochemical and Photobiological Sciences 10:242-260.

Halac, S. R., S. D. Guendulain-García, V. E. Villafañe, E. W. Helbling, and A. T. Banaszak. 2013. Responses of tropical plankton communities from the Mexican Caribbean to solar ultraviolet radiation exposure and increased temperature. Journal of Experimental Marine Biology and Ecology 445:99-107.
Halac, S. R., V. E. Villafañe, and E. W. Helbling. 2010. Temperature benefits the photosynthetic performance of the diatoms Chaetoceros gracilis and Thalassiosira weissflogii when exposed to UVR. Journal of Photochemistry and Photobiology B: Biology 101:196-205.

Helbling, E. W., A. G. J. Buma, P. Boelen, H. J. van der Strate, M. V. Fiorda Giordanino, and V. E. Villafañe. 2011. Increase in Rubisco activity and gene expression due to elevated temperature partially counteracts ultraviolet radiation-induced photoinhibition in the marine diatom Thalassiosira weissflogii. Limnology and Oceanography 56:1330-1342.

Helbling, E. W., A. G. J. Buma, M. K. de Boer, and V. E. Villafañe. 2001. In situ impact of solar ultraviolet radiation on photosynthesis and DNA in temperate marine phytoplankton. Marine Ecology Progress Series 211:43-49.

Helbling, E. W., P. Carrillo, J. M. Medina-Sánchez, C. Durán, G. Herrera, M. Villar-Argaiz, and V. E. Villafañe. 2013. Interactive effects of vertical mixing, nutrients and ultraviolet radiation: in situ photosynthetic responses of phytoplankton from high mountain lakes in Southern Europe. Biogeosciences 10:1037-1050.

Helbling, E. W., B. E. Chalker, W. C. Dunlap, O. Holm-Hansen, and V. E. Villafañe. 1996. Photoacclimation of Antarctic marine diatoms to solar ultraviolet radiation. Journal of Experimental Marine Biology and Ecology 204:85-101.

Helbling, E. W., V. E. Villafañe, M. E. Ferrario, and O. HolmHansen. 1992. Impact of natural ultraviolet radiation on rates of photosynthesis and on specific marine phytoplankton species. Marine Ecology Progress Series 80:89-100.

Hillebrand, H., C. D. Dürselen, D. Kirschtel, U. Pollingher, and T. Zohary. 1999. Biovolume calculation for pelagic and benthic microalgae. Journal of Phycology 35:403-424.

Hodell, D. A., M. Brenner, J. H. Curtis, R. Medina-González, E. Ildefonso-Chan Can, A. Albornaz-Pat, and T. P. Guilderson. 2005. Climate change on the Yucatan Peninsula during the Little Ice Age. Quaternary Research 63:109-121.

Holm-Hansen, O., and B. Riemann. 1978. Chlorophyll a determination: improvements in methodology. Oikos 30:438-447.

IPCC (Intergovernmental Panel on Climate Change). 2013. Climate change 2013. The physical science basis. Cambridge University Press, New York.

Karentz, D., J. E. Cleaver, and D. L. Mitchell. 1991. Cell survival characteristics and molecular responses of Antarctic phytoplankton to ultraviolet-B radiation. Journal of Phycology 27: 326-341.

Kauffer-Michel, E. F., and C. L. Villanueva-Aguilar. 2011. Retos de la gestión de una cuenca construida: La Península de Yucatán en México. Aqua-LAC 3:81-91.

Korbee Peinado, N., R. T. Abdala Díaz, F. L. Figueroa, and E. W. Helbling. 2004. Ammonium and UV radiation stimulate the accumulation of mycosporine like amino acids in Porphyra columbina (Rhodophyta) from Patagonia, Argentina. Journal of Phycology 40:248-259.

Margalef, R. 1983. Limnología. Ediciones Omega, S. A. Barcelona, Spain.

McComb, A. J., and J. A. Davis. 1993. Eutrophic waters of Southwestern Australia. Fertilizer Research 36:105-111.

Morris, D. P., H. E. Zagarese, C. E. Williamson, E. G. Balseiro, B. R. Hargreaves, B. E. Modenutti, R. Moeller, and C. P. Quemaliños. 1995. The attenuation of solar UV radiation in 
lakes and the role of dissolved organic carbon. Limnology and Oceanography 40:1381-1391.

Nava-Ruiz, V. M., and F. Valadez. 2012. Flora planctónica de laguna Lagartos, Quintana Roo. Revista Mexicana de Biodiversidad 83:561-582.

Osburn, C. L., and D. P. Morris. 2003. Photochemistry of chromophoric dissolved organic matter in natural waters. Pages 185-217 in E. W. Helbling and H. Zagarese (editors). UV effects in aquatic organisms and ecosystems. Royal Society of Chemistry, Cambridge, UK.

Paerl, H. W. 1988. Nuisance phytoplankton blooms in coastal, estuarine, and inland waters. Limnology and Oceanography 33:823-847.

Paerl, H. W., and J. Huisman. 2008. Blooms like it hot. Science 320:57-58.

Paul, V. J. 2008. Global warming and cyanobacterial harmful algal booms. Advances in Experimental Medicine and Biology 619:239-257.

Porra, R. J. 2002. The chequered history of the development and use of simultaneous equations for the accurate determination of chlorophylls $a$ and $b$. Photosynthesis Research 73: 149-156.

Reddell, J. R. 1981. A review of the cavernicole fauna of Mexico, Guatemala, and Belize. Texas Memorial Museum, University of Texas at Austin Bulletin, Austin, Texas.

Sánchez, M., J. Alcocer, E. Escobar, and A. Lugo. 2002. Phytoplankton of cenotes and anchialine caves along a distance gradient from the northeastern coast of Quintana Roo, Yucatan Peninsula. Hydrobiologia 467:79-89.

Schmitter-Soto, J. J., F. A. Comín, E. Escobar-Briones, J. Herrera-Silveira, J. Alcocer, E. Suárez-Morales, M. ElíasGutiérrez, V. Díaz-Arce, L. E. Marín, and B. Steinich. 2002. Hydrogeochemical and biological characteristics of cenotes in the Yucatan Peninsula (SE Mexico). Hydrobiologia 467: $215-228$.

Smith, V. H. 2003. Eutrophication of freshwater and coastal marine ecosystems. Environmental Science and Pollution Research 10:126-139.
Sobrino, C., and P. J. Neale. 2007. Short-term and long-term effects of temperature on photosynthesis in the diatom Thalassiosira pseudonana under UVR exposures. Journal of Phycology 43:426-436.

Tavera, R., E. Novelo, and S. López. 2013. Cyanoprokaryota (Cyanobacteria) in karst environments in Yucatán, México. Botanical Sciences 91:27-52.

Valadez, F., G. Rosiles-González, A. Almazán-Becerril, and M. Merino-Ibarra. 2013. Planktonic cyanobacteria of the tropical karstic lake Lagartos from the Yucatan Peninsula, Mexico. Revista de Biología Tropical 61:971-979.

Van de Poll, W. H., and A. G. J. Buma. 2009. Does ultraviolet radiation affect the xanthophyll cycle in marine phytoplankton? Photochemical and Photobiological Sciences 8:12951301.

Villafañe, V. E., A. T. Banaszak, S. D. Guendulain-García, S. M. Strauch, S. R. Halac, and E. W. Helbling. 2013. Influence of seasonal variables associated with climate change on photochemical diurnal cycles of marine phytoplankton from Patagonia (Argentina). Limnology and Oceanography 58:203-214.

Villafañe, V. E., A. G. J. Buma, P. Boelen, and E. W. Helbling. 2004. Solar UVR-induced DNA damage and inhibition of photosynthesis in phytoplankton from Andean lakes of Argentina. Archiv für Hydrobiologie 161:245-266.

Villafañe, V. E., and F. M. H. Reid. 1995. Métodos de microscopía para la cuantificación del fitoplancton. Pages 169-185 in K. Alveal, M. E. Ferrario, E. C. Oliveira and E. Sar (editors). Manual de Métodos Ficológicos. Universidad de Concepción, Concepción, Chile.

Vincent, W. F. 2009. Effects of climate change on lakes. Pages 5560 in G. E. Likens (editor). Encyclopedia of Inland Waters. Elsevier, Oxford, UK.

Wahl, B., and F. Peeters. 2014. Effect of climatic changes on stratification and deep-water renewal in Lake Constance assessed by sensitivity studies with a 3D hydrodynamic model. Limnology and Oceanography 59:1035-1052.

Zar, J. H. 1999. Biostatistical analysis. $4^{\text {th }}$ edition. Prentice Hall, Englewood Cliffs, New Jersey. 